\title{
Structural and typological model of internal conflict in personality
}

T. M. Shapran

\author{
Zhytomyr Ivan Franko State University, Zhytomyr, Ukraine \\ Corresponding author. E-mail: shafrik2008@ukr.net
}

Paper received 05.09.18; Accepted for publication 10.09.18.

https://doi.org/10.31174/SEND-PP2018-175VI73-12

\begin{abstract}
The article provides the results of research of internal personal conflict phenomenon. The analysis of various approaches to determination of content of the term "internal personal conflict" is proposed herein. In the framework of depth psychology, scientific study of internal conflicts is analyzed from the point of psychoanalytical theory, individual psychology, analytical psychology and existential psychoanalysis. Among other foreign directions, internal personal conflict is considered in the framework of neo-Freudian direction in psychology, German psychological school, humanistic psychology, and existential and cognitive directions in psychology. Furthermore, conflictogens of internal personal conflicts were identified in the theory of psychosocial development of personality, transactional analysis and psychodrama. Among domestic psychologists, the content of internal personal conflict is considered in the framework of activity theory. Also, the content of internal personal conflict was analyzed in the works of contemporary researchers. A number of scholars were singled out, who consider the internal conflict through the prism of consciousness. Scientific study of internal conflicts among various elements in the system of internal structure of personality was described. Views of scholars, who discover conflictogens in the spheres of motivation, values and sense of self, were analyzed. Theories of authors, who find conflictogens in ambivalence of interrole interaction of personality, were considered. A number of scholars were singled out, who consider the essence of internal conflict through the prism of contradictions between Real Self and Ideal Self. It was discovered that no single approach to determination of content of the term "internal conflict" exists. Likewise, the absence of integrated approach to studying of internal personal conflict as psychological phenomenon was determined. Foreign, as well as domestic scholars interpret the content of internal personal conflict in the framework of own psychological approaches, however, it is common for all approaches to understand the internal personal conflict as a collision of divergent desires of a person, opposition of one part of self to another, contradictory attitude of a person towards other people and self. The article makes an attempt to classify the existing in psychological literature views regarding determination of internal personal conflict content. Two major groups of theories were identified. The first, more numerous group, comprises the researches that consider internal personal conflict on the personal level (S. Freud, C. Jung, K. Rogers, A. Maslow, E. Fromm, V. Frankl, I. Yalom, K. Lewin, L. Festinger, V. Merlin, O. Leontiev, V. Myasishchev, F. Vasilyuk, L. Bozhovich, A. Yancupov, A. Shipilov, V. Stolin, O. Fantalova). The second - on the interpersonal level (E. Ericson, A. Adler, K. Horney, E. Berne, J. Moreno, N. Grishina, B. Bratus', B. Zeigarnik). Integration of these approaches, as well as consideration that a person cannot exist outside the society, gave us the basis for identification of two structural components of internal conflict: individually-personal and social. Basing on the Self-concept phenomenology, the core structure of internal personal conflict was identified, which consists of three planes: "Real Self", "Ideal Self" and "Socially acceptable Self". Analysis of interaction of core components of internal conflict allowed us to determine the types of internal personal conflicts. The "Ideal self" - "Real self" internal conflict type occurs when a person is simultaneously influenced by equal in force and oppositely directed desires and opportunities. The "Real self" - "Socially acceptable self" internal conflict type occurs when equal in force and oppositely directed abilities and needs come into opposition. And the "Ideal self" -"Socially acceptable self" type occurs under the effect of simultaneous contradiction between desires and needs. The article provides structural and typological model of internal conflict in personality and specifies the definition of the term "internal personal conflict".
\end{abstract}

Key words: internal personal conflict, conflictogens, personal level of internal conflict, interpersonal level of internal conflict, types of internal personal conflicts.

Introduction. In the second decade of the 21 st century, when access to any kind of information is open, and finding of needed answers to questions is a matter of not just hours or minutes, but sometimes even seconds, the humanity faces a challenge of quick and correct selection of accurate and true information. Of course, this facilitates the development of analytical and synthetizing thinking of people. However, not everyone possesses the ability of rapid assessment and giving preference to one or another stimulus in the information space. In 2014 Mental Health Atlas of World Health Organization [23] it is stated that psychological disorders account for almost $10 \%$ of world medical issues. Research of statistical data conducted by "Center for Health Statistics of Ministry of Health of Ukraine" [19] indicates that 1706070 Ukrainians suffered from mental and behavioral disorders in 2015, which constitutes $2.3 \%$ of total population of Ukraine. Being in the state of continuous emotional tension, stress or frustration leads to emergence of internal personal conflicts.

Brief overview of related articles. Issue of internal personal conflicts is not new for psychological science. Back in 1917, S. Freud in his work "Introductory Lectures on Psycho-Analysis" defines conflictogens of structural com- ponents of personality, and K. Lewin in his work "Resolving Social Conflicts" describes the very essence of internal personal conflict. Study of internal conflict in personality is based on the structure of the personality itself, on role and existential theories. Therefore, psychological literature does not provide a single approach to studying of internal contradictions of personality in the process of choosing individually significant motives, values, attitudes, roles, or behaviors.

Aim. The very absence of the integrated approach to studying of internal conflicts, which will be the basis for practical realization of model of non-conflicting personal competence, had predetermined our choice of research topic "Structural and typological model of internal conflict in personality".

Materials and methods. Trying to classify existing in psychological literature views on determination of content of internal personal conflict, it is possible to identify two major groups of theories. The first, more numerous group, comprises the researches that consider internal personal conflict on the personal level. Thus, S.Freud's classical psychoanalytical theory [16] considers internal personal conflict as a constant battle between three structural com- 
ponents of self - "Id", "Ego", and "Super-Ego", and C. Jung's theory [21] reflects on this issue through the prism of personal insecurities.

In the framework of humanistic direction in psychology, K. Rogers [13] associates the emergence of internal conflict with counteraction between a person's false conscious and unconscious self-evaluation of its Self-concept and Ideal Self, and A. Maslow [9] - with the desire of a person to reach the highest level of realization of needs - selfactualization. In the framework of neo-Freudian psychology, E. Fromm [17] interprets internal personal conflict as an "existential dichotomy" of contradictions between life and death, freedom and security, which are naturally inherent in any personality, and existential psychoanalyst $\mathrm{V}$. Frankl [5] describes it as an "existential frustration", which is the result of battle between desire to find the meaning of life and existential vacuum. Another representative of existential psychology, I. Yalom [5], considers internal personal conflict as a result of unconstructive attempts to overcome anxiety of freedom, death, meaningless, responsibility.

K. Lewin [22] develops the "field theory" and based upon it states that in order for internal personal conflict to emerge it is necessary that an individual is simultaneously affected by oppositely directed forces of equal value.

L. Festinger [5], the representative of cognitive psychology, explains the emergence of internal conflict (cognitive dissonance) through recognition of divergence of unexpectedly acquired knowledge or behavior manifestations that are opposite in their content to previously possessed knowledge or previously used behavior manifestations.

Among the domestic scholars, who considered internal personal conflict on the personal level, the contribution of V. Merlin can be distinguished, who in his book "Problems of the Experimental Psychology of Personality" [10] describes the essence of internal conflict as a subjectively unresolved situation between previously existing or new contradictions that emerge among features, relations and actions of an individual. According to the representative of Kharkiv psychological school O. Leontiev [8], internal personal tension is generated by contradictions between significance and individual content of a person, and $\mathrm{V}$. Myasishchev [12], the founder of Petersburg psychotherapy school, distinguishes dichotomy of subjective and objective emerging factors of internal personal conflict, and the conflict itself is considered by him as a disruption of connections between subsystems of the very structure of personality.

A number of domestic scholars study internal personal conflict through the prism of consciousness. Thus, according to F. Vasilyuk [6], inconsistency and contradictions of internal world of an individual act as the conflictogens of internal personal conflict, and according to L. Bozhovich [4] - it is the dual orientation of constant contradiction between conscious and unconscious parts of human life. Conflictogens among elements of internal structure of personality - sphere of motivation - are found by A. Yancupov and A. Shipilov [2], among sphere of values and sense - by V. Stolin [14] and O. Fantalova [15].
The second, less numerous group of researches, includes theories that consider internal personal conflict on the interpersonal level. Thus, E. Ericson [20], the founder of Theory of Psychosocial Development, associates prerequisites for emergence of internal personal conflict with inability to successfully overcome all crises of psychosocial development, and A. Adler [1], the founder of Individual Psychology, associates it with the insecurity of inferiority, which is developed during the childhood under the influence of adverse social factors. K. Horney [18], psychoanalyst of neo-Freudian period, relates it to clash of craving to satisfy own desires with the desire to be in security, to attitude of personality to other people and expectations of esteem of self by other people.

Other researchers from this group find conflictogens of internal conflicts in ambivalence of interrole interaction of personality. Thus, E. Berne [3], the founder of transactional analysis explains internal personal conflict through intersection of interactions of sub-personalities of three Egostates - Father, Adult, and Child. J. Moreno [11], the founder of Psychodrama, associates the emergence of internal personal conflicts with actualized and latent roles fulfilled by each individual. According to N. Grishina [7], role internal personal conflicts emerge owing to compatibility or noncompatibility of role expectations, attitude of an individual to own role expectations. B. Bratus' and B. Zeigarnik [7] describe the essence of internal personal conflicts through contradictions between Real Self and Ideal Self.

Hence, the analysis of scientific psychological literature indicated that determination of content of internal personal conflict and, therefore, the classification of conflictogens that cause the emergence and course of internal personal conflicts are interpreted by scholars from the perspective of different psychological theories. As well, the absence of integrated approach to studying of internal personal conflict as a psychological phenomenon was identified.

Results and their discussion. Integration of all mentioned approaches to studying the internal personal conflict in two groups allowed us to identify two structural components of internal conflict in personality: individuallypersonal and social components (see fig. 1). Since a person constantly interacts with society, we believe that internal conflict emerges owing to very inability of a person to manifest its individually-personal traits because of continuous various obstacles of surrounding social environment.

Note: IC - internal conflict.

Based on Self-concept phenomenology, the core of internal conflict can be considered in three planes: "Real Self", "Ideal Self" and "Socially acceptable Self". Internal personal conflict that develops in "Real Self" plane encompasses with its content cognitive, behavioral and affective conflicting abilities of personality. Internal conflict of "Ideal Self" plane encompasses with its content cognitive, behavioral and affective conflicting desires of personality. And, during actualization of "Socially acceptable Self" plane, confrontation of divergent own needs of personality and requirements that are created for a person by its social surrounding take place. This confrontation can exist on cognitive, behavioral and affective levels. 


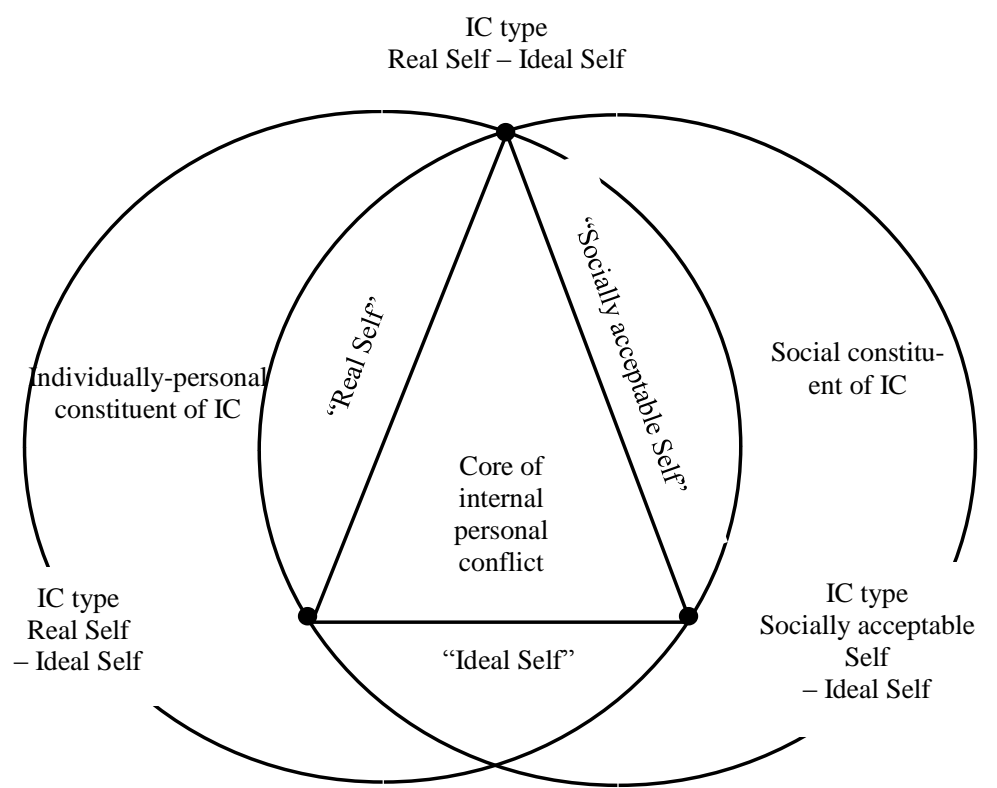

Fig.1. Structural and typological model of internal conflict in personality

Analysis of interaction of core constituents of internal personal conflict enables the differentiation of types of internal personal conflicts. Thus, simultaneous influence of equal in force and oppositely directed desires and abilities creates in personality the "Ideal Self" - "Real Self" conflict type, contradiction between equal in force and oppositely directed abilities and needs evokes the "Real Self" - "Socially acceptable Self" conflict type and simultaneous counteraction between desires and needs - the "Ideal Self" - "Socially acceptable Self" type. Graphical representation of structural and typological model of internal conflict in personality is given on figure 1 .

Conclusion. 1. Internal personal conflict is a state of conscious or unconscious inability to choose comfortable manifestation of individually-personal traits, which exists on personal and interpersonal levels.

2. Basic components of structural and typological model of internal personal conflict are two conflictogenic constituents: individually-personal and social.

3. The core of internal personal conflict comprises three planes: "Real Self", "Ideal Self" and "Socially acceptable Self".

4. Main types of internal personal conflicts are the "Ideal Self" - "Real Self" conflict type, the "Real Self"- "Socially acceptable Self" conflict type, and the "Ideal Self" - "Socially acceptable Self" type.

\section{ЛІТЕРАТУРА}

1. Адлер А. Практика и теория индивидуальной психологии. M. $-1995 .-108 \mathrm{c}$.

2. Анцупов А.Я., Шипилов А.И. Конфликтология. - М.: ЮНИТИ, 2000. $-551 \mathrm{c}$.

3. Берн Э. Игры, в которые играют люди. Люди, которые играют в игры / Э.Берн; пер. с англ. - СПб.: Университетская книга; М.: АСТ, 1996. - 398 с.

4. Божович Л.И. Проблемы формирования личности: Избр. психол. Тр. - М.: ИПП, 1995. -352 с.

5. Бурлачук Л.Ф. Психотерапия: учебник [для ВУЗов]/Л.Ф. Бурлачук, А.С.Кочарян, М.Е.Жидко.-СПб.: Питер, 2009.$496 \mathrm{c}$.

6. Василюк Ф.Е. Психология переживания. - М.: МГУ, 1984. $200 \mathrm{c}$.

7. Гришина Н.В. Психология конфликта. - СПб.: Питер, 2008. $-544 \mathrm{c}$.

8. Леонтьев А.Н. Деятельность. Сознание. Личность. - М.: Политиздат, 1975. -304 с.

9. Маслоу А. Дальнейшие рубежи развития человека / Абрахам Маслоу // Вопросы саморазвития человека: междисциплинарный теоретико-методологический сборник / под ред. В. Данченко. - Вып. 2. - Киев, 1990. - С. 3-10.

10. Мерлин В.С. Психологические конфликты // Проблемы экспериментальной психологии личности: Ученые записки. - Пермь, 1970. - С. 90-109.

11. Морено Я. Психодрама / Якоб Морено. - М.: Психотерапия, 2008. $-496 \mathrm{c}$.

12. Мясищев В.Н. Личность и неврозы. - Л.: ЛГУ, 1960. - 242 с.
13. Роджерс К.Р. Взгляд на психотерапию. Становление человека / К.Р. Роджерс. - М.: Издательская группа «Прогресс», «Универс», 1994. - 480 с.

14. Столин В.В. Самосознание личности.-М.: МГУ, 1983-288 с.

15. Фанталова Е.Б. Диагностика и психотерапия внутреннего конфликта. - Самара: БАХРАХ-М, 2001. -128 с.

16. Фрейд 3. Лекции по введению в психоанализ / Зигмунд Фрейд. - СПб.: Питер, 2003. - 480 с.

17. Фромм Э. Анатомия человеческой деструктивности. - М., 1994. $-447 \mathrm{c}$.

18. Хорни К. Наши внутренние конфликты. - СПб.: Лань, 1997. $-212 \mathrm{c}$.

19. Шафранський В.В., Дудник С.В. Психічне здоров'я населення України: стан, проблеми та шляхи вирішення / В.В. Шафранський., С.В.Дудник // Україна. Здоров'я нації. 2016. - №3. - С. 12-18.

20. Эриксон Э. Идентичность: юность и кризис / Э. Эриксон; пер. с англ.; общ. ред. и предисл. А.В. Толстых. - М.: Прогресс, 1996. - 344 с.

21. Юнг К.Г. Психологические типы / К.Г. Юнг. - М., 1995. $716 \mathrm{c}$.

22. Lewin K. Resolving social conflicts and field theory in social science / K.Lewin - Washington, D.C.: American Psychological Association, 1997. $-422 \mathrm{p}$.

23. Mental health atlas 2014 [E. resource]. - Access mode: http://apps.who.int/iris/bitstream/handle/10665/178879/9789241 565011_eng.pdf;jsessionid=B2FE00076D8A8EC60247E6A512 D61E3D?sequence=1 


\section{REFERENCES}

1. Adler A. The Practice and Theory of Individual Psychology. - 11. Moreno Ja. Psychodrama / Jakob Moreno. - M.: Psihoterapija, M. $-1995 .-108 \mathrm{~s}$. 2008. $-496 \mathrm{~s}$

2. Antsupov A.J., Shipilov A.I. Conflictology. - M.: UNITY, 2000. $-551 \mathrm{~s}$.

3. Bern Je. Games that people play. People that play games. / Je.Bern; per. s angl. - SPb.: Universitetskaja kniga; M.: AST, 1996. $-398 \mathrm{~s}$.

4. Bozhovich L.I. Problems of personality formation: Izbr. psihol. tr. - M.: IPP, 1995. $-352 \mathrm{~s}$.

12. Mjasishhev V.N. Personality and Neuroses. - L.: LGU, 1960. $242 \mathrm{~s}$.

13. Rodzhers K.R. On Becoming a Person: A Therapist's View of Psychotherapy / K.R. Rodzhers. - M.: Izdatel'skaja gruppa «Progress», «Univers», 1994. - $480 \mathrm{~s}$.

5. Burlachuk L.F. Psychotherapy: uchebnik [dlja VUZov] / L.F. Burlachuk, A.S. Kocharjan, M.E. Zhidko. - SPb.: Piter, 2009. $496 \mathrm{~s}$.

6. Vasiljuk F.E. Psychology of distress. - M.: MGU, 1984. - 200 s.

7. Grishina N.V. Psychology of conflict.- SPb.: Piter, 2008. - 544 s.

8. Leont'ev A.N. Activity. Consciousness. Personality. - M.: Politizdat, 1975. - $304 \mathrm{~s}$.

9. Maslou A. The Farther Reaches of Human Nature / Abraham Maslou // Voprosy samorazvitija cheloveka: mezhdisciplinarnyj teoretiko-metodologicheskij sbornik / pod red. V. Danchenko. Vyp. 2. - Kiev, 1990. - S. 3-10.

10. Merlin V.S. Psychological conflicts // Problemy jeksperimental'noj psihologii lichnosti: Uchenye zapiski. - Perm', 1970. -

14. Stolin V.V. Self-consciousness of personality. - M.: MGU, 1983 $-288 \mathrm{~s}$.

15. Fantalova E.B. Diagnosis and psychotherapy of internal conflict. - Samara: BAHRAH-M, 2001. - $128 \mathrm{~s}$.

16. Frejd Z. Introductory Lectures on Psycho-Analysis / Zigmund Frejd. - SPb.: Piter, 2003. $-480 \mathrm{~s}$.

17. Fromm Je. The Anatomy of Human Destructiveness. - M., 1994. $-447 \mathrm{~s}$

18. Horni K. Our Inner Conflicts. - SPb.: Lan', 1997. - 212 s.

19. Shafrans'kyj V.V., Dudnyk S.V. Mental health of the Ukrainian population: condition, problems and solutions / V.V. Shafrans'kyj, S.V. Dudnyk // Ukrai'na. Zdorov'ja nacii'. - 2016. №3. - S. 12-18

20. Jerikson Je. Identity: Youth and Crisis / Je. Jerikson; per. s angl.; obshh. red. i predisl. A.V. Tolstyh. - M.: Progress, 1996. - 344 s. S. 90-109. 